\title{
Iron(IV) hexahydrazide clathrochelate complexes: the chronic toxicity study
}

\author{
V.B. Dukhnitsky ${ }^{1}$, L.H. Kalachniuk ${ }^{1}$, I.M. Derkach ${ }^{1 *}$, S.S. Derkach ${ }^{1}$, I.O. Fritsky², M.O. \\ Plutenko ${ }^{2}$
}

${ }^{1}$ National University of Life and Environmental Sciences of Ukraine, Kyiv, Ukraine. *Corresponding author E-mail: Irina1215@ukr.net

${ }^{2}$ Taras Shevchenko National University of Kyiv, Kyiv, Ukraine

\section{Received: 10.12.2019. Accepted 20.01.2020}

\begin{abstract}
One of the main tasks in the fight against anemia is to carry out preventive measures, to develop and to introduce new preparations containing iron, to provide the pharmaceutical market with anti-anemic agents. That's why to investigate the chronic toxic effect of Iron(IV) hexahydrazide clathrochelate (new iron-containing drug) in mice was the article's aim. The study of chronic toxic effect of Iron(IV) clathrochelate was performed on 45 white mice (19-25 g) separated into 3 groups: control (I) and two experimental (II and III). Animals of II and III groups were daily fed the water solution of Iron(IV) clathrochelate at a rate of 125.8 and 251.6 $\mathrm{mg} / \mathrm{kg}$ of body weight, respectively. It was monitored the dynamics of body weight of white mice, relative coefficients of the mass of internal organs, hemoglobin content and morphological parameters of blood, biochemical indices of blood serum on the 10th, 20th and 30th day of the experiment. It was established a decrease of body weight by $16-21 \%$ and relative weight indices of internal organs (liver, kidney, heart, and spleen) - by 5- 43\% in white mice of II and III experimental groups, respectively. Changes in the morphological composition of the blood showed stimulation of leukocytopoiesis. A significant decrease in creatinine (hypocreatinemia) and uric acid (hypouricemia) was observed, which indicates an increase in the filtration capacity of the renal glomeruli. Complex studies of the effect of Iron(IV) clathrochelate solution (at a dose of 125.8 and $251.6 \mathrm{mg} / \mathrm{kg}$ of body weight) did not cause any visible signs of intoxication and death of animals at the first time. Iron(IV) clathrochelate solution (at a dose of 125.8 $\mathrm{mg} / \mathrm{kg}$ of body weight) is demonstrated more safe effect.
\end{abstract}

Keywords: Toxicity; Clathrochelate; Body weight; Internal organs coefficient; Morphology; Biochemistry; White mice

\section{Introduction}

Throughout the world, the timely implementation of preventive measures is one of the main tasks in the fight against anemia, so it does not lose the relevance of the development and implementation of new iron-containing drugs to provide the pharmaceutical market with anti-anemic agents. In this context, one of the promising groups of iron compounds is the so-called clathrochelates or macrobicyclic complexes. Alimentary anemia is a clinical-hematologic syndrome caused by impaired hemoglobin synthesis and decreased red blood cell count. In living organisms, it occurs as a consequence of deficiency of irreplaceable factors of mineral and vitamin nutrition, first of all, iron, copper, cobalt, zinc, vitamins $C$ and $B_{12}$ and others (Bonkovsky \& Herbert, 1991; Walter et al., 2003; Killip \& Bennett, 2008; Ganz, 2013). At the same time, anemia can be a symptom complex that accompanies numerous pathological processes. We have previously reported the study of the effect of Iron(IV) clathrochelate on the body of white mice (Dukhnitsky et al., 2018) and the study of its cumulative properties in rats (Dukhnitsky et al., 2019). It should be noted that such research is relevant in this respect. These issues are poorly understood, and are so widely developed in Ukraine for the first time and are of great theoretical importance for science and practical relevance for veterinary medicine in the conservation of pigs' livestock and the production of high biological and sanitary products. Conditions' deviations of keeping and feeding of animals, movement, vaccinations, diagnostic researches, and other zoo-veterinary measures to a great extent reduce the resistance of an organism, cause pathological conditions and so on. These negative aspects of housekeeping can be minimized by the pharmacocorrection of the metabolic process in the body. One of the positive properties that significantly expands the use of iron traceelement is its anti-anemic pharmacological effect. Given the importance of the problem of therapy and prevention of anemic conditions, we assume the possibility of creating drugs from the iron in the new valence IV. In addition, the available arsenal of means of pharmacological correction of the iron deficit is represented by iron dextran complexes, which mainly consists of Iron(III) (Derkach, 2017). Low-valence iron preparations for veterinary medicine have been studied previously (Maes et al., 2011; Streyl et al., 2019; Cui et al., 2018; Kim et al., 2018; Todoriuk et al., 2018). However, the pharmacokinetics and pharmacodynamics of the high valence iron have not yet been studied, which is a prerequisite for preclinical studies of new substances (Kotsiumbas, 2006). Therefore, in view of the above, the purpose of the study was to determine the effect of Iron(IV) hexahydrazide clathrochelate on the dynamics of body weight of white mice, relative ratios of internal organs, hematologic and biochemical parameters of blood and serum of white mice after its repeated administration to animals.

\section{Materials and Methods}

Studies of chronic toxicity of Iron(IV) clathrochelate $\mathrm{Na}_{2}[\mathrm{Fe}(\mathrm{L}-6 \mathrm{H})] \cdot 2 \mathrm{H}_{2} \mathrm{O}(\mathrm{L}-$ macrobicyclic hexahydrazide ligand) were performed on white mice weighing 19-25 g, formed into three groups of 15 white mice each: mice group I (control) - received water; mice of group II were fed a solution of Iron(IV) clathrochelate at a rate of $125.8 \mathrm{mg} \mathrm{kg}^{-1}$ body weight of a white mouse (1/10 DL $\mathrm{L}_{50}$ of the 
test compound); mice of group III were fed a solution of Iron(IV) clathrochelate at a rate of $251.6 \mathrm{mg} \mathrm{kg}^{-1}$ body weight (1/5 DL 50 of the test compound). The animals were kept in the conditions of the vivarium of the Faculty of Veterinary Medicine of the National University of Life and Environmental Sciences of Ukraine, with constant air temperature and humidity in the premises. Feeding the mice provided a standard diet with constant access to water/aqueous solution of Iron(IV) clathrochelate. Before the experiment, laboratory animals of all groups were kept for an adaptation period of 10 days. Deviations in the behavioral responses of mice in both experimental and control groups were not observed. During the whole experiment, the animals were monitored and taken into account the general condition, nature, and degree of activity, coordination of movement, the presence of tremors, convulsions, paresis, paralysis, excretions of the eyes, nose, discoloration of the skin and appetite. White mice were also weighed and noted changes in their body weight. To determine the relative coefficients of the mass of the internal organs, conducting morphological and biochemical studies on the 10th, 20th, and 30th days of the experiment, under the conditions of light ether anesthesia, it was euthanized 5 animals from each group. A sampling of biological material was performed by following the "General Ethical Principles of Animal Experimentation" (Ukraine, 2001) and per under the provisions of the European Convention on the Protection of Vertebrate Animals (Strasburg: Council of Europe 18.03.1986). The determination of morphological and biochemical parameters of blood and blood serum was performed by conventional methods (Vlizlo et al., 2012). The results obtained were processed by the method of variational statistics using an Excel computer program, and the results of the mean values were considered statistically significant at $\mathrm{P} \leq 0.05$ (Gerasimenko et al., 2000).

\section{Results}

Experimental studies have shown the way to drink by white mice the Iron(IV) in the form of clathrochelate at doses of $125.8 \mathrm{mg} \mathrm{kg}$ ${ }^{1}$ of body weight and $251.6 \mathrm{mg} \mathrm{kg}^{-1}$ of body weight did not cause any visible signs of intoxication and death of animals (Table 1 ). On the 10th and 20th days of observation, the experimental animals remained appetite, behavioral responses were adequate, reflecting the normal functional state of the central nervous system. On the 30th day, the correlation pattern of values of the used doses of the test substance with the depressed state of mice in the experimental groups was noted. The wool lost its luster, was tousled, the feces were soft consistency, and body weight decreased compared to the mice in the control group.

Table 1. The dynamics of the body weight of white mice during long-term use of Iron(IV) clathrochelate solution (here and then $M$ $\pm m, n=5)$.

\section{Group of animals At the beginning of the experiment}

\section{Body weight, $g$ \\ On 10th day On 30th day}

\begin{tabular}{lcccc} 
I Control & $22.2 \pm 1.16$ & $23.6 \pm 1.12$ & $25.0 \pm 1.05$ & $27.2 \pm 1.16$ \\
II Experimental & $21.8 \pm 0.58$ & $22.6 \pm 0.51$ & $23.8 \pm 0.37$ & $22.8 \pm 0.37^{*}$ \\
III Experimental & $22.0 \pm 1.00$ & $23.0 \pm 1.0$ & $24.0 \pm 0.84$ & $21.6 \pm 0.93^{* *}$ \\
\hline
\end{tabular}

Note: The degree of significance $-*-\mathrm{P}<0.05, * *-\mathrm{P}<0.01, * * *-\mathrm{P}<0.001$.

It was found that the bodyweight of white mice in the experimental groups was slightly greater on the 10th day, did not differ from that of mice in the control group on the 20th day, whereas on the 30th day, significantly decreased by $16 \%$ and by $21 \%$ in mice treated with Iron(IV) clathrochelate at the dose of 125.8 and $251.6\left(\mathrm{mg} \mathrm{kg}^{-1}\right.$ ) of body weight), respectively (Table 1). In addition, changes in the mass of individual organs were important indicators that reflect the level of metabolic processes in the body of animals during their intoxication (Table 2).

Table 2. Relative mass ratios of the internal organs of white mice during long-term use of Iron(IV) clathrochelate solution.

\section{Organ Group of animals}

Liver

I Control

II Experimental

III Experimental

I Control

Heart

II Experimental

III Experimental

I Control

Kidneys

II Experimental

III Experimental

I Control

Spleen

II Experimental

III Experimental

\section{On 10th day}

\section{The time of the experiment performing}

$6.2 \pm 0.13$
$7.2 \pm 0.18^{* * *}$
$7.8 \pm 0.68$
$0.6 \pm 0.04$
$0.7 \pm 0.03$
$0.7 \pm 0.05$
$1.9 \pm 0.08$
$2.2 \pm 0.09 *$
$2.3 \pm 0.10^{*}$
$1.2 \pm 0.17$
$1.3 \pm 0.12$
$1.4 \pm 0.18$

On 20th day

$6.3 \pm 0.29$
$6.6 \pm 0.23$
$5.9 \pm 0,59$
$0.7 \pm 0.04$
$0.6 \pm 0.03$
$0.6 \pm 0.05$
$2.0 \pm 0.15$
$2.3 \pm 0.30$
$2.5 \pm 0.07 *$
$1.0 \pm 0.07$
$1.1 \pm 0.12$
$0.7 \pm 0.12 *$

\section{On 30th day}

$6.7 \pm 0.32$

$6.4 \pm 0.21$

$5.8 \pm 0.23 *$

$0.7 \pm 0.03$

$0.5 \pm 0.03^{* *}$

$0.4 \pm 0.06 * *$

$1.9 \pm 0.26$

$1.8 \pm 0.07$

$1.7 \pm 0.12$

$1.2 \pm 0.20$

$1.0 \pm 0.12$

$0.9 \pm 0.11$

Note: See Table 1.

When analyzing the coefficients of the mass of the internal organs of white mice on the 10th day, we observed an increase in the masses of all organs studied in the animals of the experimental groups, and at dose of $251.6 \mathrm{mg} / \mathrm{kg}$ of body weight (III experimental group), these changes were more pronounced than at dose of $125.8 \mathrm{mg} / \mathrm{kg}$ of body weight. On the $20^{\text {th }}$ day, only a significant decrease in the relative weight ratio of the liver by $6 \%$ and the spleen by $30 \%(P<0.05)$ was established in animals of the III experimental group compared with those in the control group. 
On the 30th day of the experiment, changes in the relative mass ratios of the internal organs of mice tended to decrease in the experimental groups compared to the indicators in animals of the control group. The relative weight ratio of such organs as the liver was less by $5 \%$ and $13 \%$, the heart - by $29 \%(P<0.001)$ and $43 \%(P<0.001)$, the kidneys - by $5 \%$ and $11 \%$, and spleen - by $17 \%$ and $25 \%$ in mice of the II and III experimental groups, respectively. The above testifies to the excessive loading of Iron(IV) clathrochelate on these organs of mice. The blood system reflects changes in homeostasis of the body due to the toxic effects of the test substances (Table 3).

Table 3. Hemoglobin content and blood morphological parameters of white mice during long-term use of Iron(IV) clathrochelate solution.

\section{Parameters}

Hemoglobin,
$\mathrm{g} \mathrm{L}^{-1}$
Erythrocytes,
$\mathrm{T} \mathrm{L}^{-1}$
Hematocrit, \%
Leukocytes,
$\mathrm{g} \mathrm{L}^{-1}$

Color indicator

\section{Group of animals}

I Control

II Experimental

III Experimental

I Control

II Experimental

III Experimental

I Control

II Experimental

III Experimental

I Control

II Experimental

III Experimental

I Control

II Experimental

III Experimental

\section{The time of the experiment performing}

On 10th day On 20th day On 30th day

$105.9 \pm 1.45$
$99.3 \pm 1.26^{* *}$
$96.9 \pm 0.70^{* *}$
$6.9 \pm 0.11$
$7.5 \pm 0.13^{* *}$
$7.9 \pm 0.16^{* *}$
$35.6 \pm 0.96$
$36.0 \pm 1.41$
$39.0 \pm 0.71^{*}$
$5.6 \pm 0.28$
$9.1 \pm 0.24 * * *$
$11.8 \pm 1.01^{* *}$
$0.9 \pm 0.05$
$0.8 \pm 0.03$
$0.9 \pm 0.04$

$103.9 \pm 0.61$

$102.1 \pm 0.75$

$100.7 \pm 0.38^{* *}$

$7.4 \pm 0.12$

$7.3 \pm 0.11$

$7.6 \pm 0.12$

$33.7 \pm 0.87$

$33.6 \pm 1.03$

$37.4 \pm 0.74 *$

$6.2 \pm 0.34$

$7.6 \pm 0.31^{*}$

$9.3 \pm 0.24 * * *$

$1.0 \pm 0.07$

$1.0 \pm 0.03$

$1.0 \pm 0.07$

Note: See Table 1.

The hemoglobin content was significantly lower by 6 and $8 \%$ in the blood of mice of the II and III experimental groups, respectively, than in the animals of the control group on the 10th day, by 2 and $3 \%$, respectively, on the 20th day, and it almost did not differ in animals of both experimental groups from those of the control group on the 30th day.

On the 10th day, the erythrocyte count was significantly higher by 9 and $14 \%(P<0.01)$ compared to the control in the blood of mice of II and III experimental groups, respectively. The indicators of the control and experimental groups were within the physiological values on the 20th and 30th days of observation. The hematocrit was within the physiological values in animals of the II experimental group within 30 days and exceeded by $10,11,5 \%(P<0.01)$ in the animals of the III experimental group compared to the control on the 10th, 20th and 30th days of the experiment, respectively. Under the influence of Iron(IV) clathrochelate solution, the leukocyte count was significantly higher in the blood of mice in the experimental groups than in the control throughout the study period, which is evidence of leukocytopoiesis stimulation. Thus, on day 10 , their numbers were higher in $1.6(P<0.001)$ and $2.1(\mathrm{P}<0.01)$ times in the blood of animals of the II and III experimental groups, respectively, than the indicator in the control. On day 20 , their count was higher in 1.2 times $(P<0.05)$ and 1.5 times $(P<0.001)$ in the blood of the animals of the II and III experimental groups, respectively. On day 30, leukocyte counts in the blood of mice of the II and III experimental groups differed slightly from the control indicator. The color index was at the same level in animals of the control and experimental groups during 30 days. The indices of the proteins and non-protein nitrogen compounds metabolism, enzymes activity, and glucose and inorganic phosphorus content were the most changed among the biochemical parameters of rats' blood serum (Table 4).

Proteins have many functions and some of them are the maintenance of the constancy of oncotic pressure, the pH of the blood and the level of cations in it, and an important role in the formation of immunity, complexes with carbohydrates, lipids, hormones, and other substances. The total protein content of the blood serum was significantly lower in mice of the experimental groups than that of the control group mice (Table 4). Thus, the total protein content was less by $9 \%(P<0.001), 5 \%(P<0.001)$ and $2 \%$ in the blood serum of mice in the II experimental group (dose of Iron(IV) clathrochelate of $125.8 \mathrm{mg} / \mathrm{kg}$ of body weight), on the 10th, 20th and 30th day, respectively, than those of the animals in the control group. The total protein content of the blood serum was less than the control value by $17,12,10 \%(P<0.01)$ in mice of the III experimental group (dose of Iron(IV) clathrochelate of $251.6 \mathrm{mg} / \mathrm{kg}$ of body weight) on the 10th, 20th and 30th day, respectively, that indicates pronounced hypoproteinemia under the influence of Iron(IV) clathrochelate.

Under the influence of Iron(IV) clathrochelate, hyperalbuminemia was developed in animals of the experimental groups, the severity of which was dependent on the dose of the test substance. Thus, in mice of the II experimental group, the blood serum albumin content was higher by $7 \%(P<0.05)$ and $2 \%(P<0.01)$ than ones in animals of the control group on the 10 th and 20 th days, respectively. In mice of the III experimental group, it was also greater by 11 and $7 \%(P<0.05)$ than the control values on the 10th and 20th days, respectively. On the 30th day, the blood serum albumin content in mice of the experimental groups was at the same level as the control group of animals. The use of Iron(IV) clathrochelate caused a decrease in serum glucose in mice of II and III experimental groups. Thus, its level was below the control indicator by 6 and 15\%, on the 10 th day, and by 16 and $23 \%$ on the 20th day, respectively. On the 30th day, in the blood serum in mice of the experimental groups, glucose levels were almost indistinguishable from controls. 
Table 4. Biochemical parameters of blood serum in mice during long-term use of Iron(IV) clathrochelate solution.

Parameters

Total protein, $\mathrm{g} \mathrm{L}^{-1}$

Albumin, \%

Glucose, $\mathrm{mmol} \mathrm{L}^{-1}$

$\mathrm{ALT}, \mathrm{mmol}(\mathrm{h} \cdot \mathrm{L})^{-1}$

AST, mmol (h.L $)^{-1}$

$A L P, \mathrm{mmol}(h \cdot L)^{-1}$

Creatinine, $\mu \mathrm{mol} \mathrm{L} \mathrm{L}^{-1}$

Uric acid, $\mathrm{mmol}^{-1}$

Calcium, $\mathrm{mmol} \mathrm{L}^{-1}$

Phosphorus, mmol L¹

\section{Group of animals}

I Control

II Experimental

III Experimental

I Control

II Experimental

III Experimental

I Control

II Experimental

III Experimental

I Control

II Experimental

III Experimental

I Control

II Experimental

III Experimental

I Control

II Experimental

III Experimental

I Control

II Experimental

III Experimental

I Control

II Experimental

III Experimental

I Control

II Experimental

III Experimental

I Control

II Experimental

III Experimental

\section{On 10th day}

\section{The time of the experiment performing}

\section{On 20th day}

\section{On 30th day}

$65.9 \pm 0.21$
$60.1 \pm 0.61 * * *$
$55.0 \pm 1.0 * * *$
$22.8 \pm 0.52$
$24.3 \pm 0.17 *$
$25.3 \pm 0.49 * *$
$4.8 \pm 0.08$
$4.5 \pm 0.16$
$4.1 \pm 0.16^{* *}$
$10.3 \pm 0.23$
$11.1 \pm 0.29 *$
$12.3 \pm 0.06 * * *$
$136.6 \pm 1.77$
$173.4 \pm 1.12^{* * *}$
$230.5 \pm 1.42 * * *$
$198.4 \pm 0.48$
$246.7 \pm 2.03 * * *$
$254.2 \pm 1.80^{* * *}$
$182.5 \pm 1.1$
$173.9 \pm 1.58^{* *}$
$163.3 \pm 2.11^{* * *}$
$277.7 \pm 3.99$
$173.9 \pm 1.58 * * *$
$172.9 \pm 0.99 * * *$
$2.5 \pm 0.07$
$2.5 \pm 0.05$
$2.6 \pm 0.11$
$5.9 \pm 0.07$
$5.4 \pm 0.04 * * *$
$5.2 \pm 0.08 * * *$

$64.4 \pm 0.37$
$61.1 \pm 0.40^{* * *}$
$56.4 \pm 1.51^{* *}$
$25.9 \pm 0.64$
$26.4 \pm 0.82$
$27.6 \pm 0.28^{*}$
$4.4 \pm 0.10$
$3.7 \pm 0.05^{* * *}$
$3.4 \pm 0.05^{* * *}$
$9.7 \pm 0.19$
$10.6 \pm 0.43$
$11.4 \pm 0.37^{* *}$
$130.3 \pm 0.66$
$155.4 \pm 1.29 * * *$
$211.2 \pm 1.51^{* * *}$
$208.3 \pm 0.75$
$221.2 \pm 3.44^{*}$
$240.7 \pm 3.31^{* * *}$
$180.2 \pm 0.79$
$165.2 \pm 1.66^{* * *}$
$158.6 \pm 0.93^{* * *}$
$302.9 \pm 2.77$
$246.7 \pm 1.75^{* * *}$
$229.6 \pm 0.18^{* * *}$
$2.4 \pm 0.09$
$2.4 \pm 0.10$
$2.5 \pm 0.03$
$6.1 \pm 0.11$
$5.6 \pm 0.13^{*}$
$5.5 \pm 0.11^{*}$

$65.0 \pm 0.64$

$63.5 \pm 1.86$

$58.6 \pm 0.86 * * *$

$26.3 \pm 0.41$

$26.0 \pm 0.32$

$26.4 \pm 0.13$

$4.6 \pm 0.02$

$4.5 \pm 0.24$

$4.9 \pm 0.09 *$

$10.3 \pm 0.19$

$10.0 \pm 0.07$

$11.0 \pm 0.27 *$

$140.8 \pm 0.97$

$145.5 \pm 1.64 *$

$204.5 \pm 1.11^{* * *}$

$181.5 \pm 0.66$

$180.4 \pm 2.25$

$214.2 \pm 0.66 * * *$

$178.4 \pm 0.43$

$160.6 \pm 0.71 * * *$

$155.6 \pm 1.30 * * *$

$320.8 \pm 3.06$

$301.8 \pm 0.77^{* *}$

$254.1 \pm 1.54 * * *$

$2.5 \pm 0.09$

$2.5 \pm 0.08$

$2.5 \pm 0.13$

$6.2 \pm 0.12$

$6.2 \pm 0.15$

$6.1 \pm 0.04$

Note: See Table 1.

Enzymes play a crucial role in ensuring normal metabolism, which is very important for maintaining homeostasis.

According to the results of our studies, the blood serum ALT activity in mice of the II and III experimental groups was significantly higher than one in the control group on the 10th and 20th days of the experiment. Thus, in rats of the II experimental group, ALT activity was higher by $8 \%$ and $9 \%$ than the control indicator on 10th and 20th days, respectively, and it was almost no different from the indicator in the control group on the 30th day. In the rats of the III experimental group, blood serum ALT activity was significantly higher by 19,18 and $7 \%$ than ones in the control on the 10th, 20th and 30th days, respectively.

A similar trend was observed in AST activity change in the blood serum of animals. Thus, in the II and III experimental groups, on the 10th day, this indicator increased in 1.3 and 1.7 times, respectively, on the 20th day - in 1.2 and 1.6 times, respectively, while on the 30th day, it almost did not differ from the control indicator in the mice serum of the II experimental group, and was higher in 1.5 times in the mice serum of the III experimental group. Similarly, the activity of alkaline phosphatase (ALP) in the serum of mice in the II and III experimental groups underwent significant changes compared with control on the 10th and 20th days after the use of Iron(IV) clathrochelate. Thus, on day 10, it was significantly higher 1.2 and 1.3 times, respectively; on the 20 th day - in 1.1 and 1.2 times, respectively. On the 30th day, in the serum of mice of the II experimental group, ALP activity was almost indistinguishable from the control indicator, and in the serum of mice of the III experimental group, it was higher by 1.2 times ( $P$ $<0.001)$ compared with the indicator in mice of the control group. Such biochemical parameters as creatinine and uric acid underwent significant changes under the influence of Iron(IV) clathrochelate. Thus, the creatinine content in the serum of mice of the II experimental group was less by almost $5 \%(P<0.01), 8 \%(P<0.001), 10 \%(P<0.001)$ than that in control animals on the 10th, 20th and 30th day, respectively, after administration of the preparation. In mice of the III experimental group, the serum creatinine content was lower by 11,12 and $13 \%(P<0.001)$ than the control values on the 10 th, 20th and 30th day, respectively. It was the similar tendency of significant changes in the serum uric acid level in mice of both experimental groups in comparison with control within 30 days. The persistent hypouricemia was observed. Thus, on the 30th day, the serum uric acid levels were lower by 6 and $21 \%(P<0.01)$ respectively, in mice of the II and III experimental groups compared to the control value.

The mice' blood serum total calcium content in the experimental groups was at the level of indicators in animals of the control group. In contrast, the content of inorganic phosphorus was significantly lower by 8 and $12 \%$ in the II and III experimental groups, respectively, on the 10th day and by 8 and $10 \%$, respectively, on the 20th day, compared to the indices of the control group. On the 30th day, these indicators did not differ from those of control. It is known that heavy metals are highly toxic compounds that can accumulate in the body of animals and humans, causing negative effects even at low concentrations. A special place among them is iron, which, on the other hand, is a trace element necessary for the vital activity of a living organism. The value of the biogenic element is that iron is a mandatory component of the non-protein part of hemoglobin and is a component of red blood cells and facilitates the transport of oxygen and carbon dioxide in the bloodstream. Iron is also part of myoglobin and is an oxygen depot in the organism; promotes active performance of muscles under physical activity, provides the body endurance; regulates cellular metabolism; supports the immune system. The element activates the process of phagocytosis; activates protein interferon; is involved in the elimination of toxins. Iron is also a component of many protein and enzyme systems in the organism; participates in 
the synthesis of DNA, polymer molecules. Iron is involved in cholesterol metabolism and energy exchange, regulating the process of oxygen transfer to cellular cytochromes; in the synthesis of thyroid hormones and affects the activity of the nervous system, as well as the condition of the skin. Due to its effect, the absorption of B vitamins is activated, etc. Accordingly, various pathological conditions develop in the body due to a deficiency of the Iron (Belous \& Konnic, 1991; Saito, 2014; Killip \& Bennett, 2008; Ganz, 2013; Rummianceva \& Tokareva, 2004).

Since the first studies of the biological role of the iron, hundreds of years have passed, but the physiological significance of this trace element, its form in the organism of animals in many respects remain unexplored. To date, the changes that occur due to iron deficiency in the organism various systems (with insufficient intake of the body) are insufficiently investigated.

Literature analysis shows that in recent years, the number of studies of the iron in the form of high valences has increased (Lubianova, 2010; Groves, 2006; England et al., 2014; Kaplia, 2015). However, the mechanism of their toxic effects on the body has not yet been sufficiently studied. Only a small number of scientific works on this topic are available. Note that they do not give a holistic view of the problem, no parameters of chronic toxicity, as well as toxicokinetics and toxicodynamics in the organism, etc.

We studied the dynamics of the body weight of white mice with prolonged use of Iron(IV) clathrochelate solutions. It was observed the slight decrease of body weight and significant reduced relative mass ratios of the internal organs of white mice that can demonstrate some metabolic changes (Tables 1 and 2). The similar patterns changes of body weight and some organs were determined in the iron deficiencies investigation (Aktas et al., 2014; Goto et al., 2019). Changes in the morphological composition of the blood showed stimulation of leucocytopoesis (Table 3). A significant decrease in creatinine (hypocreatininemia) and uric acid (hypouricemia) was observed, which indicates an increase in the filtration capacity of the renal glomeruli (Table 4). We believe that the main causes of the decrease in the content of non-protein compounds of nitrogen (creatinine, uric acid) in the serum of mice of the experimental groups are impaired absorption of amino acids in the intestine, reducing their decomposition. Impaired renal function may be caused by the prolonged intake of Iron(IV) clathrochelate.

\section{Conclusion}

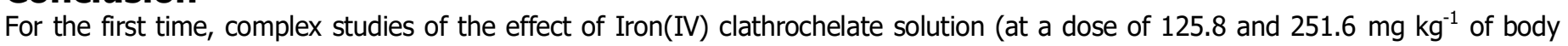
weight) were performed during the long-term use on the white mice organism, which made it possible to identify the basic patterns of metabolic disorders and physiological functions. On the 30th day of daily feeding to mice of the experimental groups of Iron(IV) clathrochelate solution at doses of 125.8 and $251.6 \mathrm{mg} \mathrm{kg}^{-1}$ of body weight resulted in decrease in body weight by 16 and $21 \%$ and the relative indices of such organs' weight as the liver - by 5 and $13 \%$, kidney - by 5 and $11 \%$, heart - by 29 and $43 \%$; spleen by 17 and 25\%, respectively. The hemoglobin content in the blood of mice of the experimental groups on the 10th and 20th days was less than the control indicator by $2-8 \%(P<0,05)$, which is evidence of inhibition of its synthesis under the influence of Iron(IV) clatrochelate at the indicated doses and on the 30th day, it did not differ from control. The erythrocytes count in the blood of mice did not differ in II and III experimental groups from that in control animals on the 30th day. Hematocrit only in mice of the III experimental group was significantly higher by $8 \%$ compared to the control. Changes in the morphological composition of the blood indicated stimulation of leukocytopoiesis The use of the solution of Iron(IV) clathrochelate in mice at doses of 125.8 and 251.6 mg $\mathrm{kg}^{-1}$ of body weight caused the development of hyperproteinemia, the severity of which was dependent on the dose of the test substance. The serum albumin content of mice was significantly higher by 2 and $11 \%$ than that in control animals on the 10 th and 20th days, respectively, and on the 30th day of the experiment, it was at the same level in the control and experimental groups.

Iron(IV) clathrochelate caused an increase in the activity of enzymes in the serum of rats of the II experimental group, and the indices did not differ from the control on the 30th day. At the same time, in the animals of the III experimental group, these values increased throughout the experiment. Feeding rats of the Iron(IV) clathrochelate solution at doses of 125.8 and $251.6 \mathrm{mg} \mathrm{kg}^{-1}$ of body weight resulted in a significant decrease in creatinine (hypocreatinemia) and uric acid (hypouricemia), indicating an increase in the filtration capacity of the renal glomeruli.

\section{References}

Aktas, G., Alcelik, A., Yalcin, A., Karacay, S., Kurt, S., Akduman, M., Savli, H. (2014). Treatment of iron deficiency anemia induces weight loss and improves metabolic parameters. Clinical therapy, 165 (2), 87-9. doi: https://doi.org/10.7471/CT.2014.1688

Belous, A. M. \& Konnic, A. T. (1991). Fiziologichna rol` zaliza. Kiev. Naukova Dumka [in Ukrainian].

Bonkovsky, S., Herbert, L. (1991). Iron and the liver. American journal medical science, 301 (1), $32-43$. https://doi.org/10.1097/00000441-199101000-00006

Commission of the European Communities: Council Directive of 18 December 1986 on the Lows, regulating the Application of Principles of Good Laboratory Practice and the Verification of Their Applications for Tests on Chemical Substances (87/18/EEC) (1991). The Rules Governing Medicinal Products in the European Community. 1, 145-146.

Cui, J., Li, Y., Yu, P., Zhan, Q., Wang, J., Chi, Y., Wang, P. (2018). A novel low molecular weight Enteromorpha polysaccharide-iron (III) complex and its effect on rats with iron deficiency anemia (IDA). International journal bioogical macromoleculs, 108, 412-418. doi: https://doi.org/10.1016/j.ijbiomac.2017.12.033

Dukhnitsky, V. B., Derkach, I. M., Plutenko, M. O., Fritsky, I. O., \& Derkach, S. S. (2018). Vyznachennja parametriv gostroi toksychnosti ferumu (IV) na bilyh myshah. Ukrainian Journal of Ecology, 8 (2), 308-312. https://doi.org/10.15421/2018_343 [in Ukrainian].

Dukhnitsky, V. B., Derkach, I. M., Plutenko, M. O., Fritsky, I. O., \& Derkach, S. S. (2019). Cumulative properties of Iron(IV) clathrochelate in rats. Visnyk PDAA, 2, 2382-46.

Derkach, I. (2017). Suchasni tendencii na vitchyznjanomu rynku ferumvmisnyh preparativ dlja tvaryn. Naukovyj visnyk Lvivskogo nacionalnogo universytetu veterynarnoi medycyny ta biotehnologij imeni S. Z. Gzhyckogo, 19 (78), 23-25. https://doi.org/10.15421/nvlvet7805 [in Ukrainian].

England, J. Bigelow, O., Katherine, M., Heuvelen, V., Farquhar, E., Martinho, M., Meier, K., Frisch, J., Münck E., \& Que L. (2014). An ultra-stable oxoiron (IV) complex and its blue conjugate base. Chemical Science, 5, 12041-215. doi: https://doi.org/10.1039/C3SC52755G/

Ganz T. (2013). Systemic iron homeostasis. Physiological review, 93 (4), 1721-1741. doi: https://doi.org/10.1152/physrev.00008 Gerasimenko, S.S., Golovach, A. V., Erina, A.M. (2000). Statistics: Textbook. Kyiv. KNEU. 110-3.

Goto, M., Suematsu, Y., Nunes, A.C.F., Jing, W., Khazaeli, M., Lau, W.L., Vaziri, N.D. (2019). Ferric citrate attenuates cardiac hypertrophy and fibrosis in a rat model of chronic kidney disease. Iran journal kidney disorges, 13 (2), 98-104. 
Groves, J. T. (2006). High-valent iron in chemical and biological oxidations. Journal of Inorganic Biochemistry, 100(4), 4344-47. https://doi.org/10.1016/j.jinorgbio.2006.01.012

Rummianceva, A. G., Tokareva, Y. N. (2004). Iron overloading diseases (hemochromatosis). Moskwa. Medpractica Press.

Kaplia, A. A. (2015). The influence of iron ions on ATP-hydrolases activity of cell membranes of rat colon smooth muscle and kidney. Ukrainian biochemical journal, 87 (1), 83-90. PMID: 26036134

Kim, J. C., Wilcock, P., \& Bedford, M. R. (2018). Iron status of piglets and impact of phytase superdosing on iron physiology: A review. Animal Feed Science and Technology. 235, 81-84.

Killip, S., Bennett, M. (2008). Iron deficiency anemia. American family physician, 15, 78 (8), 671-678.

Kotsiumbas, I. Ya. (2006) Doklinichni doslidzhennja veterynarnyh likars'kyh zasobiv. L'viv. Triada pljus [in Ukrainian].

Lubianova, I. P. (2010). Modern concepts about the metabolism of iron from the position of the occupational pathologist. Actual problems of transport medicine, 20 (2), 47-57.

Maes, D., Steyaert, M., Vanderhaeghe, C., López Rodríguez, A., de Jong, E., Del Pozo Sacristán, R., Vangroenweghe, F., \& Dewulf, J. (2011) Comparison of oral versus parenteral iron supplementation on the health and productivity of piglets. Veterinary record. 19 , 168-188. doi: https://doi.org/10.1136/vr.c7033

Saito, H. (2014). Metabolism of iron stores. Journal medical science, 76 (3-4), 235-254.

Streyl, K., Carlstron, J., Dantos, E., Mendoza, R., Islas, J.A., \& Bhushan C. (2015). Field evaluation of the effectiveness of an oral toltrazuril and iron combination (baycox $($ iron) in maintaining weaning weight by preventing coccidiosis and anaemia in neonatal piglets. Parasitological reserch, 114 (1), 1932-00. doi: https://doi.org/10.1007/s00436-015-45254-529.

Todoriuk, V. B., Hunchak,V. M., Gutyj, B. V., Gufriy, D. F., Hariv, I. I., Khomyk, R. I., \& Vasivhttps, R. O. (2018). Preclinical research of the experimental preparation "Ferosel T". Ukrainian Journal of Veterinary and Agricultural Sciences, 1, 3-9. https://doi.org/10.15421/ujvas0101

Tomyn, S., Shylin, S. I., Bykov, D., Ksenofontov, V., Gumienna-Kontecka, E., Bon, V., \& Fritsky, I. O. (2017). Indefinitely stable iron (IV) cage complexes formed in water by air oxidation. Nature Communications, 8, 1-8.

Vlizlo, V. V., Fedoruk, R. S., Ratych, I. B., Vishhur, O. I., Sharan, M. M., Vudmaska, I. V. (2012). Laboratorni metody doslidzhen u biolohii, tvarynnytstvi i veterynarii. Lviv. SPOLOM [in Ukrainian].

Walter, T., Olivares, M., Pizarro, F., Muñoz, C. (1997). Iron, anemia, and infection. Nutrition Review, 55 (4), 111-124. doi: https://doi.org/10.1111/j.1753-4887.1997.tb06462.x

\section{Citation:}

Dukhnitsky, V.B., Kalachniuk, L.H., Derkach, I.M., Derkach, S.S., Fritsky, I.O., Plutenko, M.O. (2020). Iron(IV) hexahydrazide clathrochelate complexes: the chronic toxicity study. Ukrainian Journal of Ecology, 10(1), 18-23.

(cc) EY This work is licensed under a Creative Commons Attribution 4.0. License 